\title{
ABNORMAL PHASES IN HIGH W CONTENT NICKEL BASE SUPERALLOYS AND PHASE CONTROL
}

\author{
Yunrong Zheng ${ }^{1,2}$, Shusuo $\mathrm{Li}^{1}$, Liang Zheng ${ }^{2,3}$, Yafang $\mathrm{Han}^{1,2}$ \\ ${ }^{1}$ School of Materials Science and Engineering, Beijing University of Aeronautics and Astronautics, Beijing 100083, China \\ ${ }^{2}$ Beijing Institute of Aeronautical Materials, Beijing 100095, China \\ ${ }^{3}$ School of Materials Science and Engineering, Xi'an University of Technology, Xi'an 710048
}

Keywords: Die superalloys, Solidification, Phase transformation, Mechanical properties, $\mathrm{M}_{6} \mathrm{C}$ carbides, $\alpha$ phase, $\mu$ phase

\begin{abstract}
In this paper, the forming conditions and harmful effects of the abnormal phases such as $\mathrm{M}_{6} \mathrm{C}$ carbides, $\alpha(\mathrm{W}, \mathrm{Mo})$ and $\mu$ in a series of high $\mathrm{W}$ content $\mathrm{K} 9, \mathrm{~K} 20$ and 601 alloys, which are suitable for forging die, have been studied. The abnormal phases precipitated from liquid belong to primary phases. The large blocky $\mathrm{M}_{6} \mathrm{C}$ formed in as-cast alloys, as the total amount of $(\mathrm{W}+\mathrm{Mo})$ and carbon content exceeded $18 \mathrm{wt} \%$ and $0.15 \mathrm{wt} \%$ respectively, while the carbon content less than $0.06 \mathrm{wt} \%$ promoted the formation of primary $\alpha$ and $\mu$ phases. The addition of elements such as $\mathrm{Co}$ or $\mathrm{Ru}$ and the rapid solidification exhibited a decreased tendency to precipitate $\mathrm{M}_{6} \mathrm{C}$ carbides. The primary $\mathrm{M}_{6} \mathrm{C}$ carbide is the most stable phase among the three abnormal phases and is not removed until the full melting of alloy. Contrarily, the $\alpha$ and $\mu$ are unstable phases and can transform to $\mathrm{M}_{6} \mathrm{C}$ carbides. The primary $\mathrm{M}_{6} \mathrm{C}$ carbides severely deteriorate the mechanical properties of the alloys, and the stress rupture life of the alloys at $1100^{\circ} \mathrm{C} / 118 \mathrm{MPa}$ decreased over $50 \%$, as the volume fraction of primary $\mathrm{M}_{6} \mathrm{C}$ in alloys was higher than $1.5 \%$. It was very difficult to avoid the formation of primary $\mathrm{M}_{6} \mathrm{C}$ for a heavy section forging die cast by this series alloys, therefore the compositional modification for these alloys was performed.
\end{abstract}

\section{Introduction}

Conventional highly alloyed cast Ni-base alloys drop off sharply in strength above approximately $1100^{\circ} \mathrm{C}$ because the $\gamma^{\prime}$ phase, upon which these alloys primarily depend for high temperature strength, agglomerates or goes into solution in this temperature range. The element $\mathrm{W}$ is a stabilizer of $\gamma^{\prime}$ phase and increases melting temperature, therefore some cast Ni-base superalloys containing 16 19 wt\% W were developed in United States in the 1960 's to 1970's. The representative alloys were WAZ20 [1], WAZ16 [2] and IN591-X [3]. With the development of superalloys, the content of high cost elements such as Ta and Re was continuously raised in order to improve the temperature capability of the alloys [4,5], and hence the materials cost increased dramatically [6]. For the high temperature structural materials used for the industrial gas turbine vanes and forging dies, the cost factor is one of the most important considerations in commercial competition.

In China, it was paid attention to develop a series of cast nickel based superalloys K9, K20 and Alloy 601 for potential stator vanes application of gas turbines in the past 30 years. All these alloys contain 14 16 wt \% W and belong to (Ta, Re, Hf)-free low cost alloys. Among them the conventional cast Alloy 601 possesses a superior strength corresponding to that of the first generation SC superalloys DD3 at $1100^{\circ} \mathrm{C}$ [7] and can meet the cost demand. At present, Alloy K9 has been successfully applied to large size forging dies working in the temperature range of $1050^{\circ} \mathrm{C}$ to $1100^{\circ} \mathrm{C}$. However, the alloy is very sensitive to the composition limits and cast process. Out of the narrow control range, the abnormal phase characterized by $\mathrm{M}_{6} \mathrm{C}, \mu$ and $\alpha$ (W, Mo) will appear during solidification [8]. Especially, the large blocky primary $\mathrm{M}_{6} \mathrm{C}$ carbides seriously deteriorate the mechanical properties of the alloys. Hence, the systematical investigation on forming conditions and avoidance ways of abnormal phases was carried out to provide technical support for further application of alloys in this study.

\section{Experimental Procedures}

Thirteen 5kg-master alloys with 16 22 wt\% (W+Mo) were prepared by vacuum induction melting followed by remelting and cast to the shaped test bars. The analysis compositions of these alloys are listed in Table I. The Alloy 4, 7 and 9 are denominated as K9, K20 and Alloy 601 respectively. The others are the modified composition alloys for different levels of $\mathrm{Co}, \mathrm{W}, \mathrm{Mo}, \mathrm{Ta}$ and $\mathrm{C}$.

In order to explore the forming and transforming conditions of abnormal phases, a part of specimens was heat-treated at $1230 \sim 1300^{\circ} \mathrm{C} / 0.3 \sim 0.4 \mathrm{~h}$ or thermo-exposed at $1100^{\circ} \mathrm{C} / 500 \mathrm{~h}$. The other specimens were isothermally solidified. The solidification samples with a size of $5 \times 5 \times 5 \mathrm{~mm}^{3}$ were cut from the ingots and embedded into graphite blocks with drilling holes. The samples were surrounded by slurry made of alumina powder and silicasol. This packaging can protect melts from flowing out and oxidation effectively during melting and solidification. After desiccation, the graphite blocks were heated to $1420^{\circ} \mathrm{C}$ and held for $10 \mathrm{~min}$, followed by cooling at $15{ }^{\circ} \mathrm{C} / \mathrm{min}$ to different isothermal solidification temperatures in the range of $1340 \sim 1400^{\circ} \mathrm{C}$. The samples were held at these temperatures for $10 \mathrm{~min}$ followed by water quenching.

The stress rupture life at $1050 \sim 1100^{\circ} \mathrm{C}$ and $118 \sim 147 \mathrm{MPa}$ for ascast shaped specimens was determined. The microstructures of ascast, heat-treated and stress ruptured specimens were analyzed by SEM, EDS, EPMA, XRD and optical metallography. Electrolytic extraction of minor phases in alloys was performed in a standard $10 \mathrm{ml} \mathrm{HCl}+90 \mathrm{ml}$ methanol $+1 \mathrm{~g}$ tartaric solution at a voltage of $3 \sim 5 \mathrm{~V}$ for $2 \mathrm{~h}$. The volume percent of $\mathrm{M}_{6} \mathrm{C}$ in alloys was measured by a standard method of systematic manual point count [9]. 
Table I Analysis Compositions of the Investigated Alloys, wt $\%$

\begin{tabular}{|c|c|c|c|c|c|c|c|c|c|c|c|}
\hline Alloy & $\mathrm{Cr}$ & $\mathrm{W}$ & $\mathrm{Mo}$ & $\mathrm{Al}$ & $\mathrm{Ti}$ & $\mathrm{Nb}$ & $\mathrm{Co}$ & $\mathrm{C}$ & $\mathrm{B}$ & $\mathrm{Zr}$ & $\mathrm{Ta}$ \\
\hline 1 & 2.99 & 17.50 & - & 6.06 & - & 0.98 & - & 0.15 & 0.022 & 0.50 & - \\
\hline 2 & 2.98 & 18.18 & - & 5.94 & - & 0.95 & 2.66 & 0.074 & 0.016 & 0.39 & - \\
\hline 3 & 3.42 & 17.72 & - & 5.95 & - & 1.10 & 5.04 & 0.095 & 0.023 & 0.49 & - \\
\hline 4 & 3.04 & 17.30 & - & 6.24 & - & 1.00 & 9.97 & 0.15 & 0.02 & 0.45 & - \\
\hline 5 & 3.00 & 17.80 & - & 6.22 & - & 0.94 & - & 0.19 & 0.02 & 0.49 & - \\
\hline 6 & 2.45 & 22.00 & - & 6.10 & - & 0.89 & 8.77 & 0.14 & 0.02 & 0.43 & - \\
\hline 7 & 2.98 & 14.09 & 1.93 & 5.61 & 1.15 & 2.52 & 9.93 & 0.14 & 0.02 & 0.10 & - \\
\hline $8^{*}$ & 3 & 14 & 2 & 5.5 & 1.2 & 4.5 & 10 & 0.35 & 0.02 & 0.1 & - \\
\hline 9 & 1.31 & 16.22 & 2.13 & 5.96 & 1.13 & 0.95 & 9.63 & 0.10 & 0.024 & 0.121 & - \\
\hline 10 & 1.55 & 15.46 & 1.99 & 5.44 & 1.31 & 2.52 & 9.60 & 0.14 & 0.024 & 0.076 & - \\
\hline 11 & 1.39 & 16.00 & 1.99 & 4.99 & 1.05 & 1.04 & 9.61 & 0.10 & 0.045 & 0.10 & 6.69 \\
\hline 12 & 1.28 & 19.20 & 2.12 & 5.52 & 1.10 & 2.30 & 14.79 & 0.05 & 0.026 & 0.04 & - \\
\hline 13 & 1.18 & 14.89 & 6.32 & 5.70 & 1.23 & 2.40 & 14.89 & 0.06 & 0.022 & 0.23 & - \\
\hline *Nominal compositions & & & & & & & \\
\hline
\end{tabular}

\section{Normal and Abnormal Phases}

\section{$\underline{\text { As-Cast Microstructures of Alloys }}$}

Normal microstructures of the as-cast Alloy 9, as a representative of high W content alloy, are presented in Figure 1. The microstructures consist of MC carbides, eutectic $\gamma^{\prime}$ phase in the interdendritic region and the secondary $\gamma^{\prime}$ phase distributing in the $\gamma$ matrix. Phase analysis results show that Alloy 9 contains 66.2 vol.\% $\gamma^{\prime}$ phase including about 9 vol.\% eutectic $\gamma^{\prime}$ phase, 1.2 vol.\% MC carbides and minor content of $\mathrm{M}_{3} \mathrm{~B}_{2}$ boride. It is noted that the $\gamma$ phase is absence in eutectic $\gamma^{\prime}$ phase. The results of XRD and metallography indicated that the abnormal phases such as primary $\mathrm{M}_{6} \mathrm{C}$ carbides, $\alpha(\mathrm{W}, \mathrm{Mo})$ and $\mu$ phase could exist in the modified composition alloys.

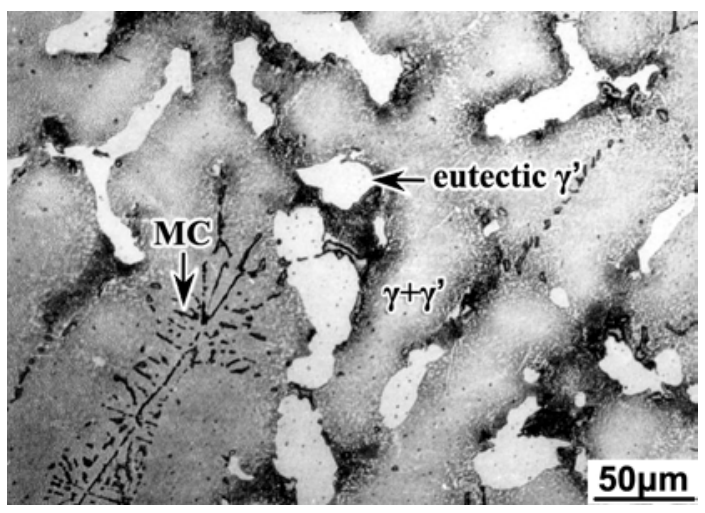

Figure 1. As-cast microstructure of Alloy 9

\section{$\underline{\text { Primary } \mathrm{M}_{6} \mathrm{C} \text { carbides }}$}

Primary $\mathrm{M}_{6} \mathrm{C}$ carbides appear in thirteen alloys listed in Table I with different amount, therefore this phase was considered as the most common phase among the abnormal phases. It has been found that primary $\mathrm{M}_{6} \mathrm{C}$ carbides exhibited the regularly angular, anchor or bar shapes. $\mathrm{M}_{6} \mathrm{C}$ carbides with the angular and bar shapes existed in all alloys and anchor shaped $\mathrm{M}_{6} \mathrm{C}$ carbides usually appeared in the alloy containing high levels of $\mathrm{W}$ and $\mathrm{C}$, such as Alloy 5 and Alloy 6. Morphologies of primary $\mathrm{M}_{6} \mathrm{C}$ carbides are shown in Figure 2. It can be observed that this carbide often coexists with eutectic $\gamma^{\prime}$ and possesses size range of $5-\sim 100 \mu \mathrm{m}$, even maximum size of $0.3 \mathrm{~mm}$. The compositions of $\mathrm{M}_{6} \mathrm{C}$ carbides determined by EDS in different alloys are represented in Table II. It can be seen from this table that $\mathrm{M}_{6} \mathrm{C}$ carbides exhibit rather fixed compositions in which levels of $(\mathrm{W}+\mathrm{Mo})$ and $(\mathrm{Ni}+\mathrm{Co})$ are $73 \sim 79 \mathrm{wt} \%$ and $17 \sim 19 \mathrm{wt} \%$ respectively.
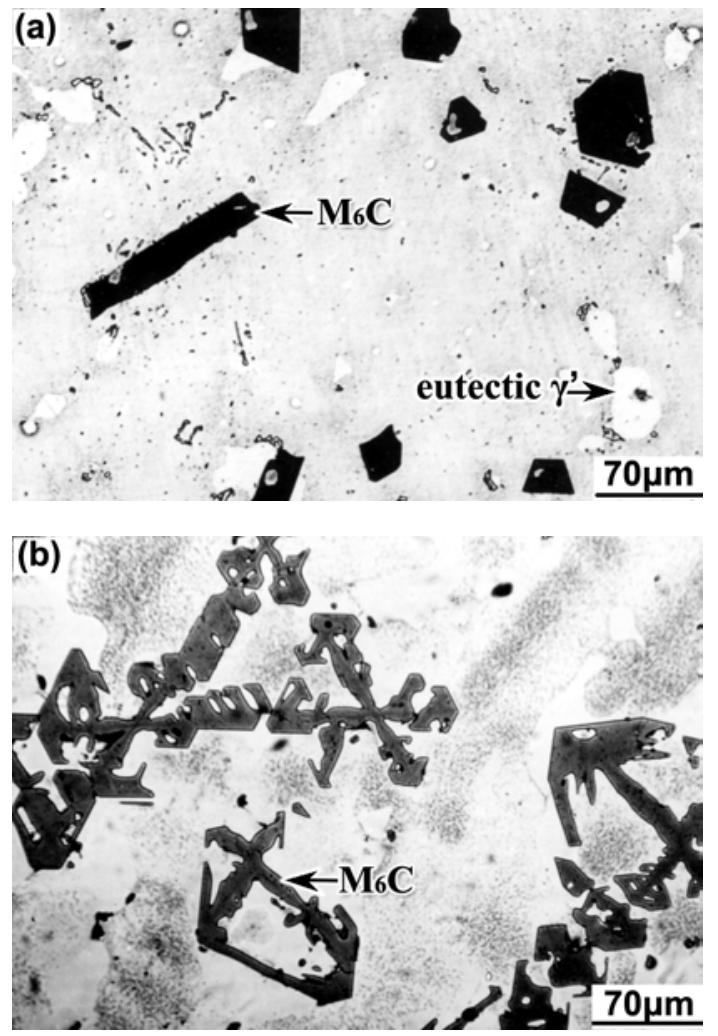

Figure 2. Micrographs of Primary $\mathrm{M}_{6} \mathrm{C}$ carbides morphologies: (a) blocky and bar shaped in Alloy 1, (b) anchor shaped in Alloy 5. 
Table II Composition of $\mathrm{M}_{6} \mathrm{C}$ carbides* in various alloys, EDS, wt $\%$

\begin{tabular}{|c|c|c|c|c|c|c|c|c|c|}
\hline Alloy & $\mathrm{W}$ & $\mathrm{Mo}$ & $\mathrm{Ni}$ & $\mathrm{Co}$ & $\mathrm{Cr}$ & $\mathrm{Nb}$ & $\mathrm{Al}$ & $\mathrm{Ti}$ & Vickers hardness at 0.49N, GPa \\
\hline 1 & 77.64 & - & 17.02 & - & 2.44 & 2.19 & 0.57 & - & 14.8 \\
\hline 5 & 79.71 & - & 12.57 & 4.29 & 2.07 & 0.95 & 0.30 & - & 15.1 \\
\hline 6 & 79.29 & - & 12.00 & 4.77 & 2.07 & 1.40 & 0.43 & - & 16.7 \\
\hline 8 & 67.52 & 5.55 & 14.06 & 4.54 & 1.96 & 5.39 & 0.44 & 0.34 & 15.0 \\
\hline 9 & 71.41 & 6.53 & 14.30 & 4.05 & 1.00 & 1.43 & 0.68 & 0.60 & 16.8 \\
\hline
\end{tabular}

$\mathrm{M}_{6} \mathrm{C}$ carbide is extremely hard and brittle. This phase has a Vickers microhardness value range of $14.8 \sim 16.8 \mathrm{GPa}$ at the load of $0.49 \mathrm{~N}$ listed in Table II, but the indentations of hardness cracked at the load of $0.98 \mathrm{~N}$.

\section{Primary $\alpha$ (W, Mo) phase}

The $\alpha(\mathrm{W}, \mathrm{Mo})$ phase existed in Alloy 6 and Alloy 11 13. This phase can be clearly revealed on the polishing surface of metallographic specimen, Figure 3(a). There are two kinds of $\alpha$ phase in different alloys: the dendritic $\alpha$ distributing everywhere,
Figure 3(b), and the small bar or blocky $\alpha$ phases only locating in eutectic $\gamma^{\prime}$, Figure 3(c). Compositions of $\alpha$ phase were determined by EPMA and are listed in Table III. This table indicates that $\alpha$ phase mainly contains elements W, Mo and other elements hardly enter into this phase, hence the phase can be expressed as $\alpha$ (W, Mo). The atomic ratio of $\mathrm{Mo} / \mathrm{W}$ in Alloy 13 reaches 0.81 , but this ratio value in $\alpha$ phase is only 0.27 , showing higher tendency of $W$ than Mo for formation of $\alpha$ phase. The Vickers microhardness test at the load of $0.49 \mathrm{~N}$ was carried out and the average hardness value of $4.52 \mathrm{GPa}$ for $\alpha$ phase was obtained.

Table III Compositions of $\alpha$ (W, Mo) and $\mu$ phase, EPMA, wt $\%$

\begin{tabular}{|c|c|c|c|c|c|c|c|c|c|}
\hline Alloy & Phase & $\mathrm{Ni}$ & $\mathrm{Co}$ & $\mathrm{Cr}$ & $\mathrm{W}$ & $\mathrm{Mo}$ & $\mathrm{Nb}$ & $\mathrm{Ti}$ & $\mathrm{Al}$ \\
\hline 11 & $\alpha$ & 0.65 & 0.15 & 0.20 & 93.45 & 5.55 & - & - & - \\
\hline \multirow{2}{*}{12} & $\alpha$ & 0.31 & 0.13 & 0.20 & 95.13 & 4.10 & 0.13 & - & - \\
\cline { 2 - 10 } & $\mu$ & 17.65 & 16.92 & 3.39 & 44.92 & 13.71 & 2.75 & 0.20 & 0.50 \\
\hline \multirow{2}{*}{13} & $\alpha$ & 0.43 & 0.15 & 0.21 & 86.92 & 12.11 & - & 0.18 & - \\
\cline { 2 - 10 } & $\mu$ & 18.30 & 17.52 & 2.94 & 28.49 & 28.39 & 4.35 & 0.23 & 0.42 \\
\hline
\end{tabular}

(a)
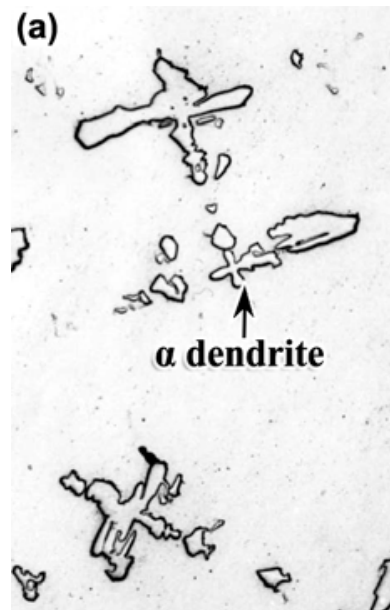

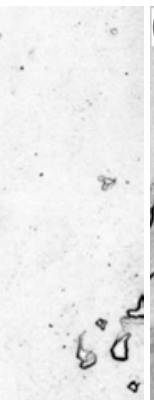

(b)
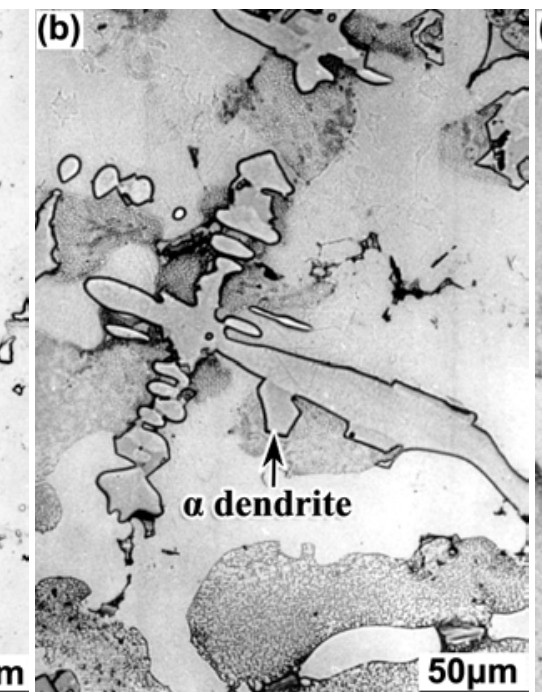

$100 \mu \mathrm{m}$

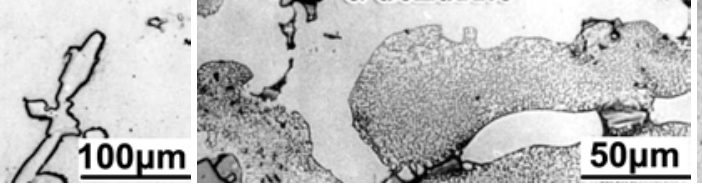

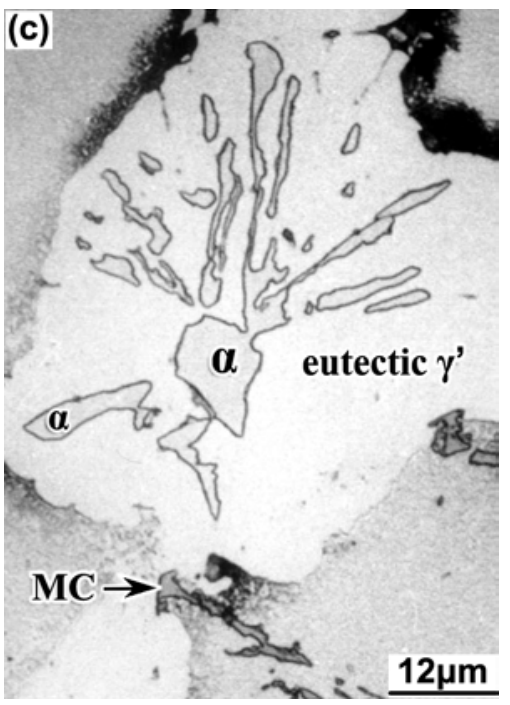

Figure 3. Morphology of $\alpha$ (W, Mo) phases: (a), (b) dendritic shaped in Alloy 6, (c) small bar or blocky shaped in Alloy 11. 


\section{Primary $\mu$ phase}

Figure 4 shows morphology of primary $\mu$ phase in Alloy 13 . The $\mu$ phase can be revealed by electrolytic etching in a $\mathrm{H}_{3} \mathrm{PO}_{4}-\mathrm{HNO}_{3}$ $\mathrm{H}_{2} \mathrm{SO}_{4}$ solution, Figure 4(a), and this phase is tinted as dark blue tone by soaking at $450^{\circ} \mathrm{C} / 30 \mathrm{~min}$ making sharp black and white contrast, Figure 4(b). The primary $\mu$ phase normally appears in the periphery of eutectic $\gamma^{\prime}$.

The EPMA results in Table III demonstrate that the elements of $\mathrm{Mo}, \mathrm{W}, \mathrm{Cr}, \mathrm{Nb}$ and $\mathrm{Co}$ are $\mu$-formers. Based on atomic percent, contents of the above mentioned elements in $\mu$ phase are much higher than those in the alloy, especially the total amount of refractory elements $(\mathrm{Mo}+\mathrm{W}+\mathrm{Cr}+\mathrm{Nb})$ in $\mu$ phase is as high as 44 47 at $\%$ which is three times higher than that of the alloy.
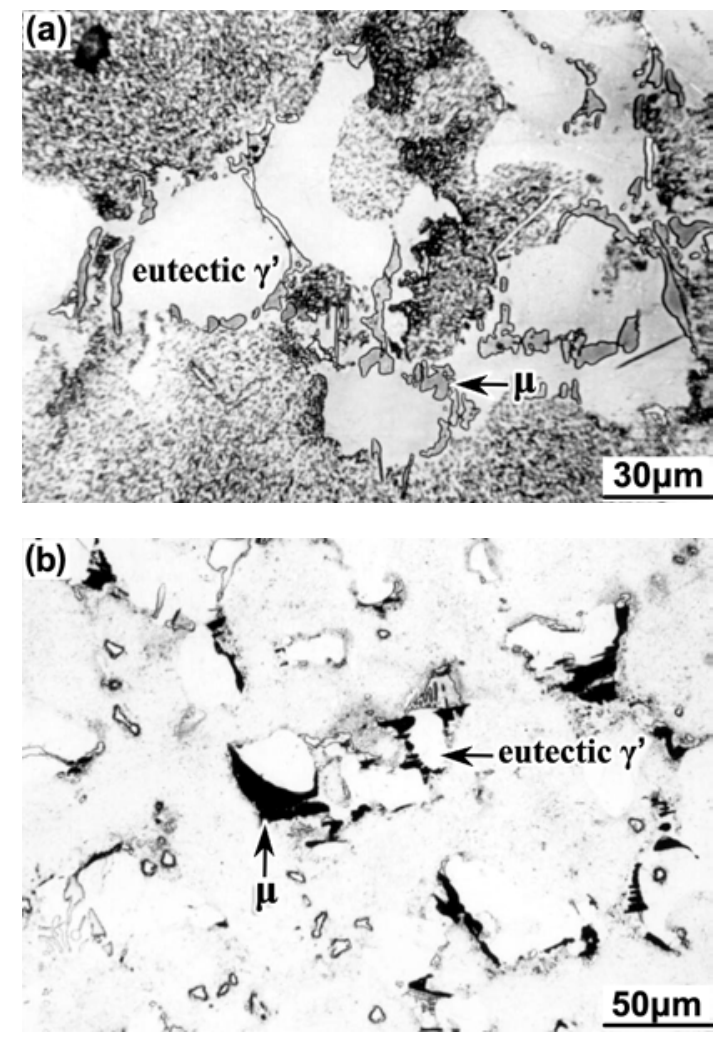

Figure 4. Primary $\mu$ phase in Alloy 13: (a) etching by mixed acid, (b) tinting.

\section{Precipitation Conditions of Abnormal Phases}

\section{Primary $\mathrm{M}_{6} \mathrm{C}$ carbides}

Metallographic experiments certified that susceptibility of the formation of $\mathrm{M}_{6} \mathrm{C}$ carbides was very different in various sections of the same casting or in different heats of alloys with same composition. For example, as specimen of Alloy 10 with $\mathrm{M}_{6} \mathrm{C}$ was heated to $1420^{\circ} \mathrm{C}$ and poured into metal chill mold, $\mathrm{M}_{6} \mathrm{C}$ was eliminated, Figure 5 (a). In contrast, large amount of $\mathrm{M}_{6} \mathrm{C}$ formed in ordinary $\mathrm{M}_{6} \mathrm{C}$-free specimen due to the remelting and slow furnace cooling, Figure 5 (b). Isothermally solidified experiments of Alloy 9 proved that long bar-shaped $\mathrm{M}_{6} \mathrm{C}$ carbides formed as shown in Figure 6 at $1375^{\circ} \mathrm{C}$ which was $20^{\circ} \mathrm{C}$ higher than that of
$\mathrm{MC}$ formation, and this precipitation could last until $1340{ }^{\circ} \mathrm{C}$. Once primary carbides form, the quantity of $\mathrm{MC}$ will decrease obviously. It is evident from the above results that the formation of $\mathrm{M}_{6} \mathrm{C}$ is closely related to the cooling rate of solidified process and the rapid solidification can prevent from precipitation of $\mathrm{M}_{6} \mathrm{C}$. Since dendtitic spacing was considered as a characterizing parameter of cooling rate during solidification of castings, a relationship between the dendritic spacing and the volume fraction of $\mathrm{M}_{6} \mathrm{C}$ carbide was measured for seven alloys, shown in Figure 7. This figure indicates that $\mathrm{M}_{6} \mathrm{C}$ does not present in the thinner sections of specimens with dendritic spacing less than $50 \mu \mathrm{m}$, except for the high carbon content Alloy 8 .
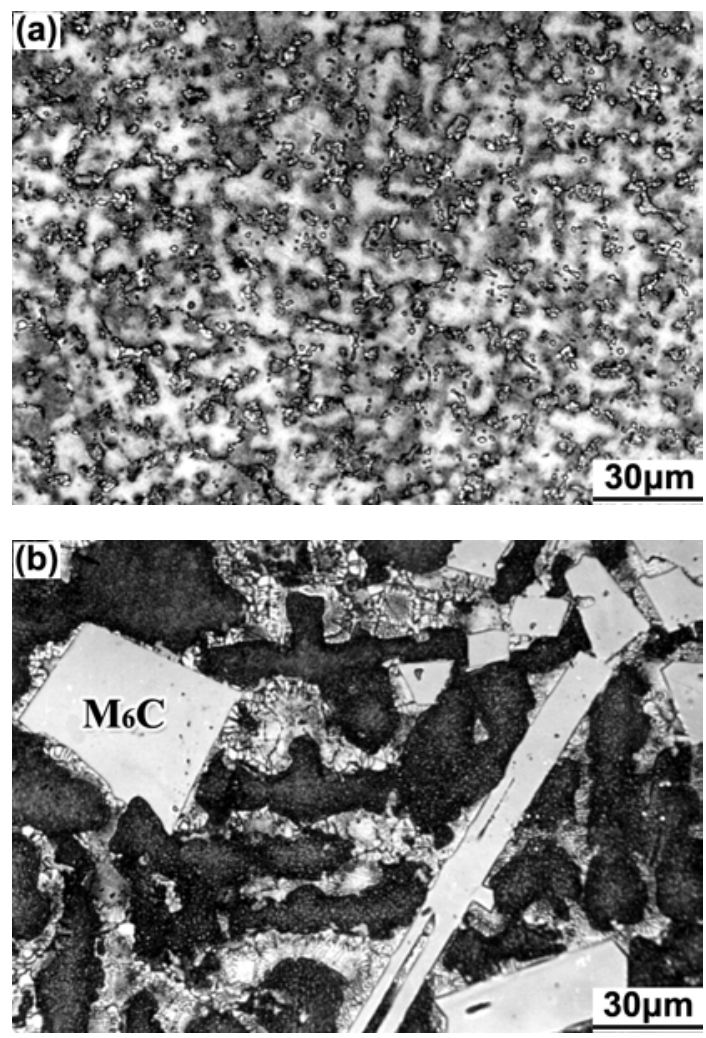

Figure 5. Tendency to form $\mathrm{M}_{6} \mathrm{C}$ carbide for Alloy 10: (a) rapid cooling in cold metal mold after remelting, (b) furnace cooling after remelting.

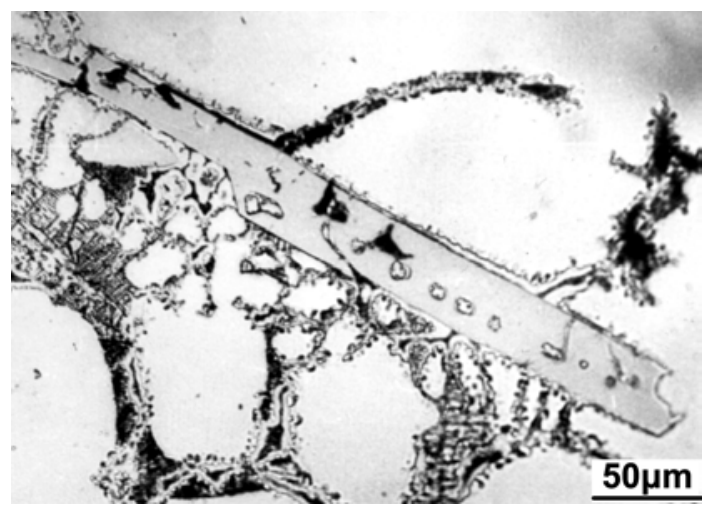

Figure 6. Long bar-shaped $\mathrm{M}_{6} \mathrm{C}$ carbide precipitated in Alloy 9 after treatment of $1420^{\circ} \mathrm{C} / 10 \mathrm{~min}+1375^{\circ} \mathrm{C} / 10 \mathrm{~min}+$ water quenching. 


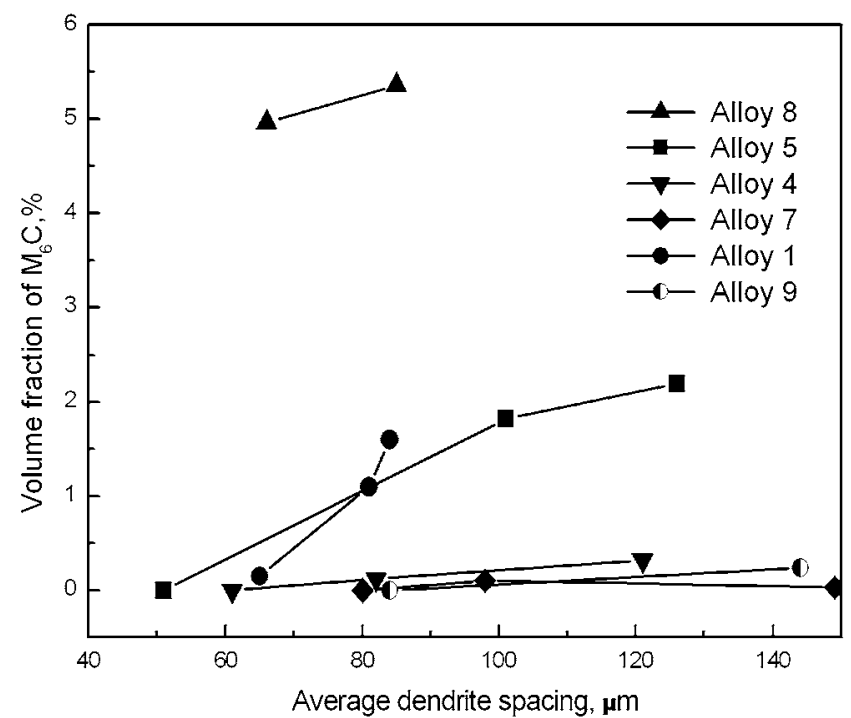

Figure 7. Relationship between the dendritic spacing and the volume percent of $\mathrm{M}_{6} \mathrm{C}$ carbides.

It can be seen from Figure 7 and Table I that elements W, Mo and $\mathrm{C}$ are strong $\mathrm{M}_{6} \mathrm{C}$-formers and primary $\mathrm{M}_{6} \mathrm{C}$ carbides easily form as the amount of $(\mathrm{W}+\mathrm{Mo})$ and carbon is over $18 \mathrm{wt} \%$ and $0.15 \mathrm{wt} \%$ in as-cast alloys respectively.

Element $\mathrm{Co}$ and $\mathrm{Ru}$ are effective retarders of $\mathrm{M}_{6} \mathrm{C}$. Accompanied by an increase of the Co content in alloys, the volume percent of primary $\mathrm{M}_{6} \mathrm{C}$ decreases significantly, Figure 8 . Addition of $10-15$ wt.\% Co is necessary to stabilize the microstructure of superalloys containing high $\mathrm{W}$ content. The element $\mathrm{Ru}$ is even stronger than Co in retarding the formation of $\mathrm{M}_{6} \mathrm{C}$ phase. Large amount of primary $\mathrm{M}_{6} \mathrm{C}$ existed in DTA specimen of Alloy 9 cooled down at the rate of $10{ }^{\circ} \mathrm{C} / \mathrm{min}$. However, no $\mathrm{M}_{6} \mathrm{C}$ appeared in DTA specimen of Alloy 9 with 3 wt.\% Ru at the same cooling rate, even though the Ru-bearing specimen was soaked for $10 \mathrm{~min}$ at $1370^{\circ} \mathrm{C}$ which is the sensitive temperature of $\mathrm{M}_{6} \mathrm{C}$ formation.

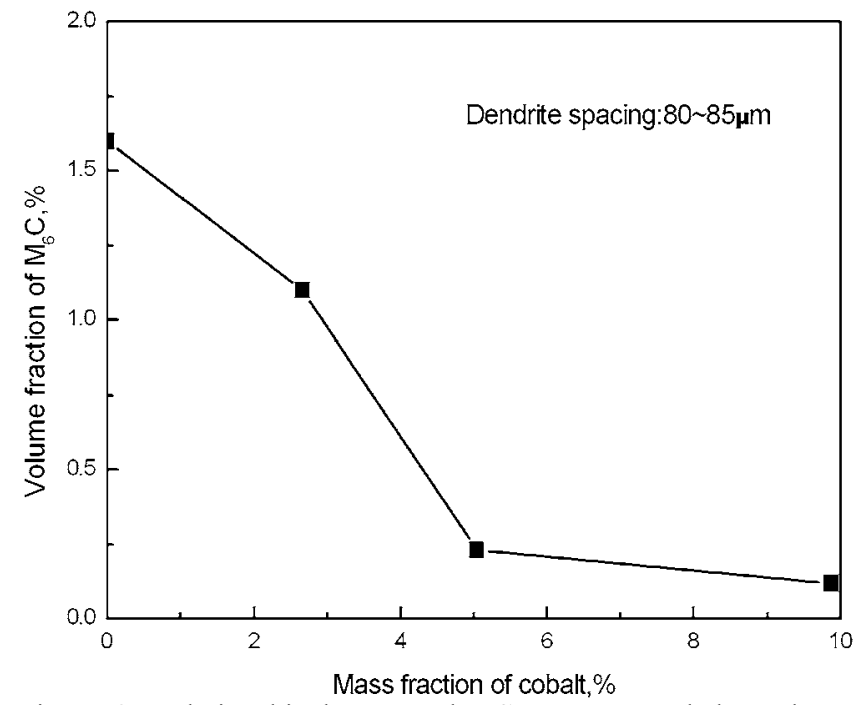

Figure 8. Relationship between the Co content and the volume percent of $\mathrm{M}_{6} \mathrm{C}$ carbide in Alloy $\mathrm{K} 9$.
Primary $\alpha(\mathrm{W}, \mathrm{Mo})$ and $\mu$ phases

The $\alpha$ (W, Mo) dendrites shown in Figure 3 (a) and (b) formed at very onset of solidification in the alloys with the content of $(\mathrm{W}+$ Mo) higher than $20 \mathrm{wt} \%$. It was demonstrated by solidified experiment that for Alloy 6, the beginning formation of $\gamma$ dendrites took place at $1380{ }^{\circ} \mathrm{C}$, whereas primary $\alpha$ (W, Mo) dendrites formed at $1385^{\circ} \mathrm{C}$, Figure 9. The similar $\alpha-\mathrm{W}$ dendrite in the Ni-W eutectic alloy was reported [11].

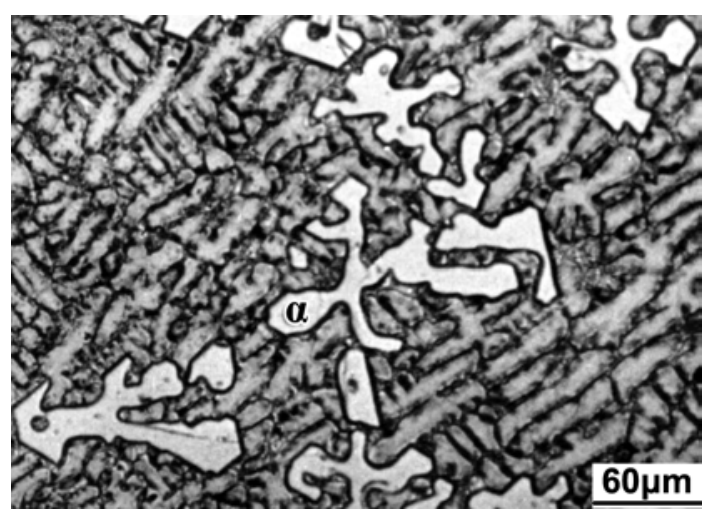

Figure 9. $\alpha(\mathrm{W}, \mathrm{Mo})$ dendrites precipitated from liquid Alloy 6 after $1420^{\circ} \mathrm{C} / 10 \mathrm{~min}+1385^{\circ} \mathrm{C} / 10 \mathrm{~min}$ and very fine $\gamma$ dendrites formed by quenching.

The small bar shaped $\alpha$ (W, Mo) phase within eutectic $\gamma^{\prime}$ shown in Figure 3 (c) is due to high content of Ta in Alloy 11. As a strong positive segregation element and $\gamma^{\prime}$-former, Ta raises the volume percent of eutectic $\gamma^{\prime}$ up to $20 \mathrm{vol} . \%$, whereas the solubility of $\mathrm{W}$ in eutectic $\gamma^{\prime}$ is far lower than that in $\gamma$ phase. During the formation of eutectic $\gamma^{\prime}$, the excess $\mathrm{W}$ precipitates in the form of $\alpha$ (W, Mo) solid solution.

In alloys containing lower than $0.06 \mathrm{wt} \% \mathrm{C}$ and higher than 18 $\mathrm{wt} \%(\mathrm{~W}+\mathrm{Mo})$, primary $\mu$ phase often appears, especially in alloys with Mo higher than $4 \mathrm{wt} \%$. The precipitated reactions of eutectic $\left(\gamma+\gamma^{\prime}\right)$ and $\mathrm{MC}$ carbide basically finish at $1270^{\circ} \mathrm{C}$ for Alloy 13 , and the residual liquid which rich in $\mathrm{W}$, Mo and poor in $\mathrm{Al}, \mathrm{C}$ is beneficial to form $\mu$ phase.

\section{Transformation of Abnormal Phases}

$\mathrm{M}_{6} \mathrm{C}$ carbide is the most stable phase in the three abnormal phases. Once this phase formed, it is impossible to be removed in a solid state. In contrast, the $\alpha$ and $\mu$ phases can transform into $\mathrm{M}_{6} \mathrm{C}$ carbides during long-term thermo-exposure or treatment of solid solution.

Transformation of $\alpha$ (W, Mo) Phase

Figure 10 represents the evidence of $\alpha$ transformation. After thermal exposure of $1100^{\circ} \mathrm{C} / 500 \mathrm{~h}$, a large part of $\mathrm{MC}$ carbide decomposed and an appreciable amount of carbon promoted the reaction of $\alpha+\mathrm{C} \rightarrow \mathrm{M}_{6} \mathrm{C}$. Therefore all small bar shaped $\alpha$ phase fully transformed into $\mathrm{M}_{6} \mathrm{C}$ carbide and large blocky $\alpha$ only transformed partially, Figure 10(a). Indentations of microhardness at the load of $0.49 \mathrm{~N}$ in transformed and untransformed regions are shown in Figure 10(b), and the hardness values and EDS compositions of the two regions are given in Table IV, in which 
compositions of some granular and plate $\mathrm{M}_{6} \mathrm{C}$ are also listed. The bar shaped $\alpha$ phase within eutectic $\gamma^{\prime}$ for Alloy 11 slowly resolves and agglomerates into the spherical particles enveloped by $\gamma$ phase during a solid solution treatment above $1260^{\circ} \mathrm{C}$. This change is more distinct at a treatment of $1290^{\circ} \mathrm{C} / 3 \mathrm{~h}$, shown in Figure $9(\mathrm{c})$.

Table IV Compositions of $\mathrm{M}_{6} \mathrm{C}^{*}$ carbides and $\alpha$ phase in Alloy 11 after $1100^{\circ} \mathrm{C} / 500 \mathrm{~h}$ thermal exposure, EDS, wt $\%$

\begin{tabular}{|c|c|c|c|c|c|c|c|c|c|c|}
\hline Phase & $\mathrm{Al}$ & $\mathrm{Ti}$ & $\mathrm{Cr}$ & $\mathrm{Co}$ & $\mathrm{Ni}$ & $\mathrm{Nb}$ & $\mathrm{Mo}$ & $\mathrm{W}$ & Ta & Vickers hardness, GPa \\
\hline Granular $\mathrm{M}_{6} \mathrm{C}$ & 0.08 & 0.06 & 1.64 & 9.44 & 18.23 & 0.95 & 10.30 & 57.66 & 1.60 & - \\
\hline Plate $\mathrm{M}_{6} \mathrm{C}$ & 0.51 & 0.14 & 1.27 & 8.71 & 21.80 & 0.40 & 6.75 & 59.31 & 1.59 & - \\
\hline $\mathrm{M}_{6} \mathrm{C}$ transformed from $\alpha$ & 0.16 & 0.07 & 1.54 & 9.28 & 15.36 & 0.00 & 6.11 & 68.90 & 0.00 & - \\
\hline Residual $\alpha(\mathrm{W}, \mathrm{Mo})$ & 0.04 & 0.01 & 0.26 & 0.52 & 2.93 & 0.00 & 6.13 & 88.88 & 1.68 & 10.6 \\
\hline
\end{tabular}
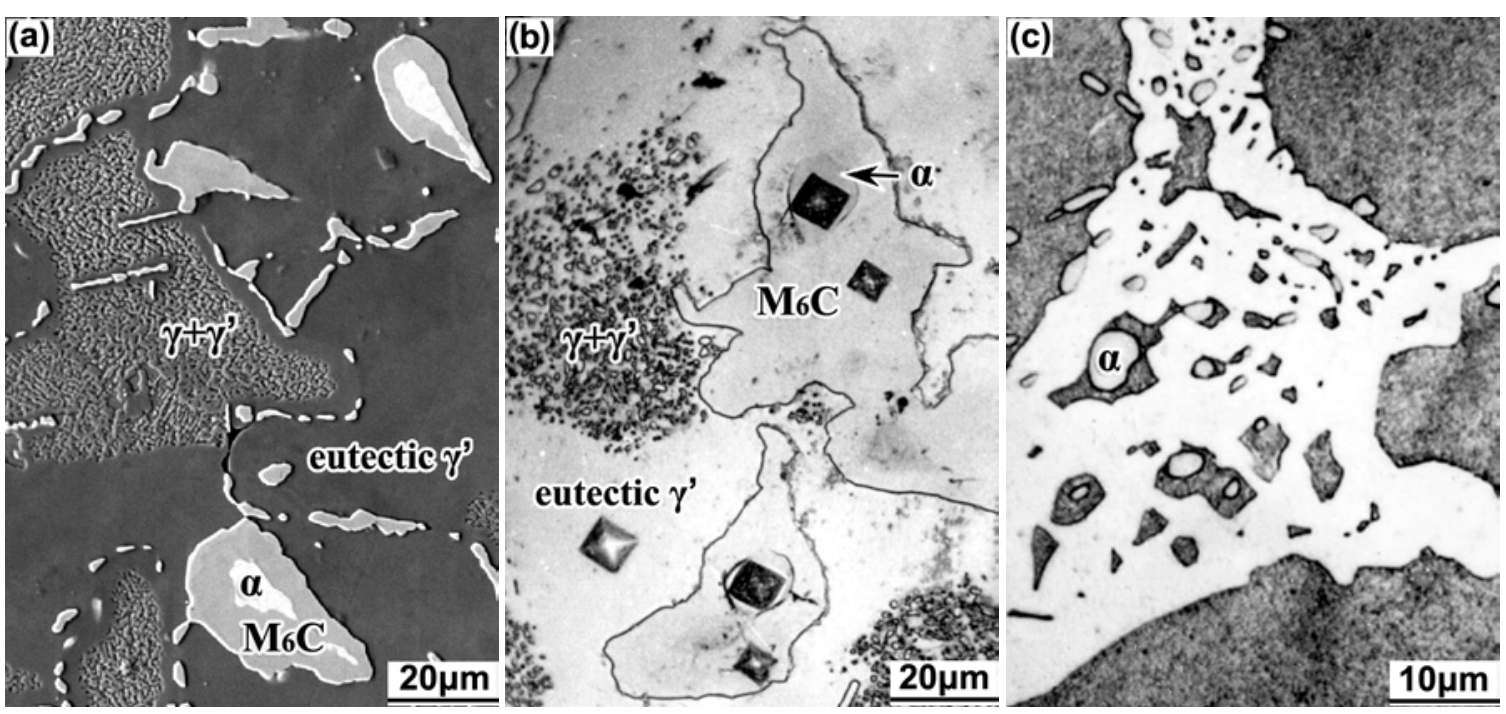

Figure 10. Transformation and resolution of $\alpha$ phase in Alloy $11:$ (a) and (b) $1100^{\circ} \mathrm{C} / 500 \mathrm{~h}$, (c) $1290^{\circ} \mathrm{C} / 3 \mathrm{~h}$.

\section{$\underline{\text { Transformation of } \mu \text { Phase }}$}

Primary $\mu$ phase is rather stable below $1100^{\circ} \mathrm{C}$ and only a few of plate $\mu$ phase at periphery of eutectic $\gamma^{\prime}$ phase resolves and changes into small blocky phase surrounded by $\gamma$ phase after thermal exposure of $1100^{\circ} \mathrm{C} / 500 \mathrm{~h}$ for Alloy 13, Figure $11(\mathrm{a})$. As temperature approaches $1200{ }^{\circ} \mathrm{C}$, the $\mu$ phase became very unstable and transformed to $\mathrm{M}_{6} \mathrm{C}$. Figure 11 (b) illustrates the microscopic appearance of $\mu$ phase dissociating to $\mathrm{M}_{6} \mathrm{C}$ after treatment of $1230^{\circ} \mathrm{C} / 30 \mathrm{~min}$ for this alloy. It can be seen from Figure 11 (b) that the ordinary $\mu$ surrounding $\gamma$ ' phase changes partially to regularly angular $\mathrm{M}_{6} \mathrm{C}$ and residual $\mu$ phase coarsens and still maintains irregular shape. After $1230^{\circ} \mathrm{C} / 2 \mathrm{~h}$, no $\mu$ phase exist in the alloy. The $\mu$ and $\mathrm{M}_{6} \mathrm{C}$ compositions were measured by EPMA and presented in Table $\mathrm{V}$. These data indicate that the $\mathrm{M}_{6} \mathrm{C}$ transformed from $\mu$ contains a higher $\mathrm{W}$ content and lower $\mathrm{Ni}, \mathrm{Co}, \mathrm{Cr}$ and Mo contents, as compared with residual $\mu$ phase.

Table V Compositions of residual $\mu$ and $\mathrm{M}_{6} \mathrm{C}$ transformed from $\mu$ phase in Alloy 13 after treatment of $1290^{\circ} \mathrm{C} / 30 \mathrm{~min}, \mathrm{EDS}$, wt $\%$

\begin{tabular}{|c|c|c|c|c|c|c|c|c|}
\hline Phase & $\mathrm{Ni}$ & $\mathrm{Co}$ & $\mathrm{Cr}$ & $\mathrm{W}$ & $\mathrm{Mo}$ & $\mathrm{Nb}$ & $\mathrm{Al}$ & $\mathrm{Ti}$ \\
\hline$\mu$ & 22.61 & 15.56 & 2.64 & 27.11 & 28.61 & 2.29 & 0.75 & 0.43 \\
\hline $\mathrm{M}_{6} \mathrm{C}^{*}$ & 14.31 & 5.59 & 0.84 & 58.24 & 17.37 & 1.78 & 0.96 & 0.55 \\
\hline
\end{tabular}



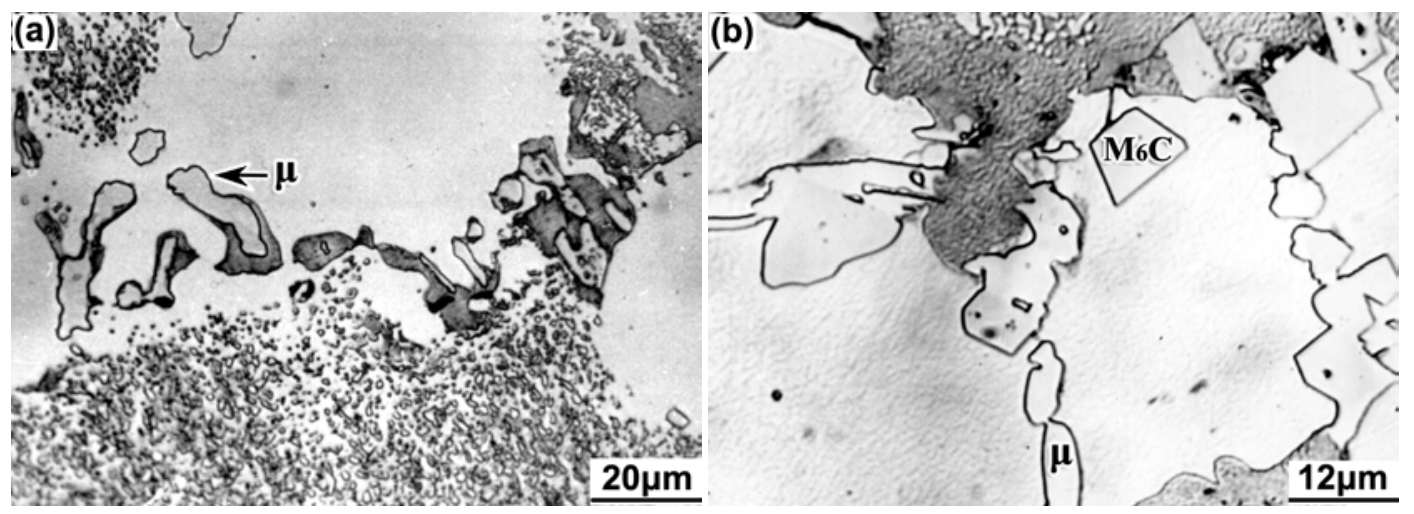

Figure 11. Resolution and transformation of $\mu$ phase in Alloy 13: (a) thermal exposure of $1100^{\circ} \mathrm{C} / 500 \mathrm{~h}$, (b) solid solution of $1230^{\circ} \mathrm{C} / 30 \mathrm{~min}$.

\section{Effect of abnormal phases on stress rupture life}

Figure 12 portrays the average stress rupture life of test bars at $1050{ }^{\circ} \mathrm{C} / 147 \mathrm{MPa}, 1080^{\circ} \mathrm{C} / 118 \mathrm{MPa}$ and $1100^{\circ} \mathrm{C} / 118 \mathrm{MPa}$. All of the low life alloys, such as Alloy 6 and 10-1, contain more than 1.5 vol. $\%$ primary $\mathrm{M}_{6} \mathrm{C}$. Alloy $10-1$ and $10-2$ belong to the same master alloy, but different cast processing. $\mathrm{M}_{6} \mathrm{C}$-free Alloy 10-2 has a rupture life of $89.5 \mathrm{~h}$ at $1080^{\circ} \mathrm{C} / 118 \mathrm{MPa}$ due to rapid cooling during remelting and pouring, whereas the stress rupture life of Alloy $10-1$ is only $16.7 \mathrm{~h}$ because of the formation of large amount of $\mathrm{M}_{6} \mathrm{C}$ during slow cooling solidification. Similarly, as compared with the cast shaped test bars, the temperature capability of Alloy 1 decreases about $40^{\circ} \mathrm{C}$ in the $\mathrm{M}_{6} \mathrm{C}$-containing specimens cut from heavy sections with a $80 \mathrm{~mm}$ diameter.

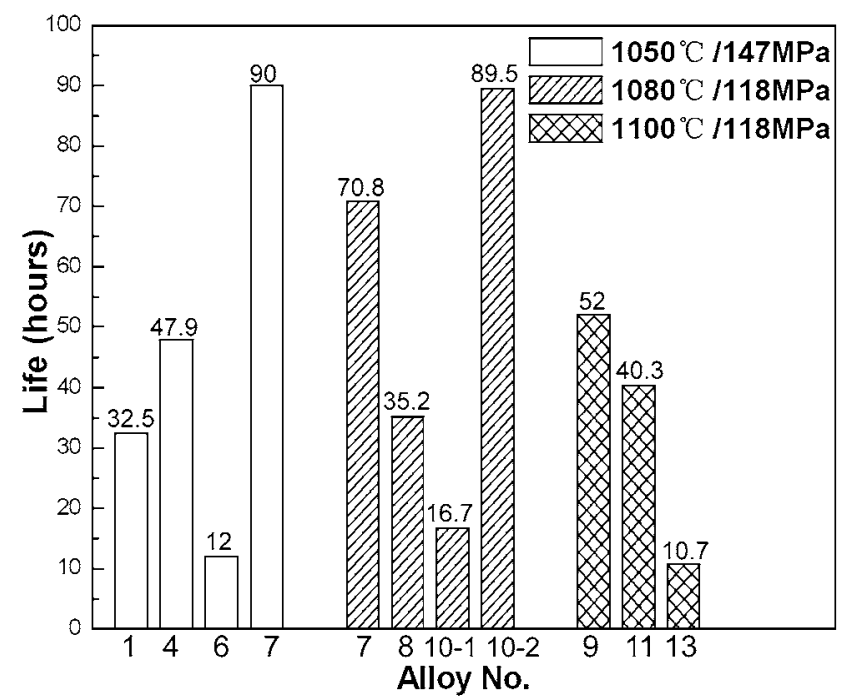

Figure 12. Stress rupture life of alloys at different temperatures and stresses.

Metallographic observations proved that cracks generally occurred at interface of $\mathrm{M}_{6} \mathrm{C} /$ matrix, as pointed by arrows in Figure 13(a). The initiated cracks propagated as cavities during stress rupture test, Figure 13(b).
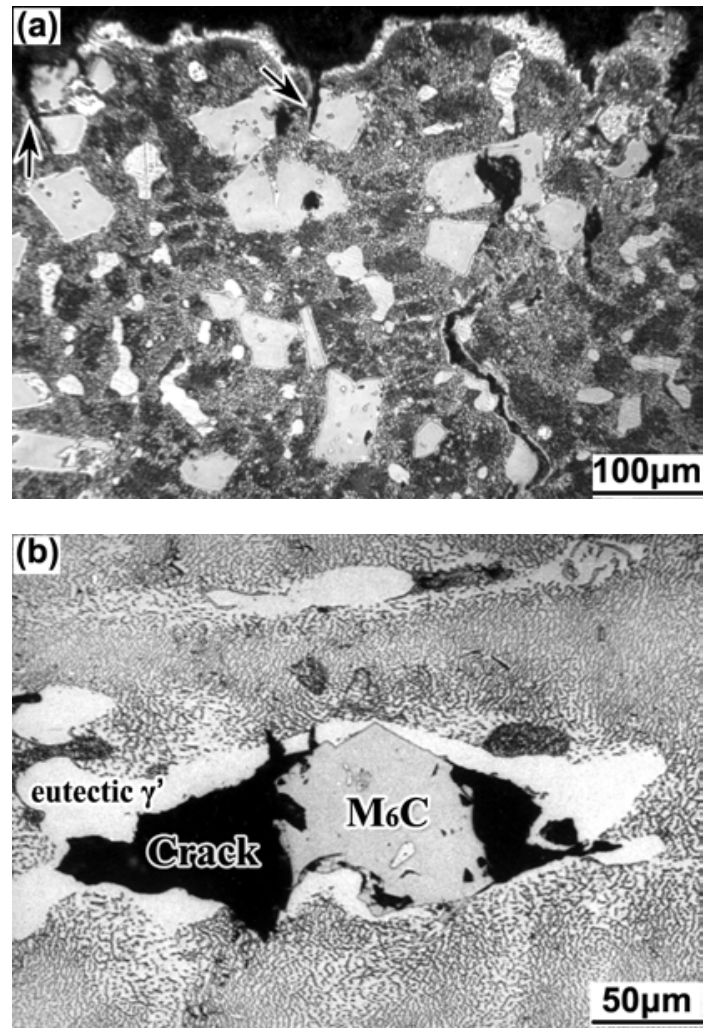

Figure 13. Stress rupture cracks deduced from primary $\mathrm{M}_{6} \mathrm{C}$ : (a) in specimen of Alloy 8 ruptured at $1080^{\circ} \mathrm{C} / 118 \mathrm{MPa}$ for $32.5 \mathrm{~h}$, (b) in specimen of Alloy 9 ruptured at $1100^{\circ} \mathrm{C} / 118 \mathrm{MPa}$ for $35.4 \mathrm{~h}$.

An appreciable amount of $\mu$ phase in alloys will degrade mechanical properties significantly. Low stress rupture life of Alloy 13 in Figure 12 is associated with $\mu$ phase existence in great quantity. Small amount of $\alpha$ (W, Mo) phase has no obvious effect on stress rupture life of alloys. For instance, Alloy 11 containing bar like $\alpha$ phase in large parts of eutectic $\gamma^{\prime}$ still possessed a $40.3 \mathrm{~h}$ rupture life. 


\section{Discussion}

It was found that Alloy K9 was a forging die material suitable for application below $1050^{\circ} \mathrm{C}$. Alloy 601 is a promising candidate due to a $20^{\circ} \mathrm{C}$ higher temperature capability than that of $\mathrm{K} 9$ and a very good stability of microstructure in the temperature range of $850 \sim 1100^{\circ} \mathrm{C}$ [12]. However, it is noteworthy that these alloys exhibit a high sensitivity of microstructure and mechanical properties to alloy composition and conditions of solidification, especially a great number of primary $\mathrm{M}_{6} \mathrm{C}$ carbides easily form in Co-free Alloy K9 cast forging die with a section size over $200 \mathrm{~mm}$, similar section size effect of cast blades was concerned as early as 1970 's and stress rupture properties of blades at different sections were measured [13]. For large size dies as heavy as tons, it is impossible to directly take specimens from die to inspect microstructure and mechanical properties. A reasonable solution is to modify the compositions of alloys in order to obtain a wide tolerance for cast variation. This study satisfied the above demands basically.

At the end of 1970's, the shortage of Co in international market promoted development of low Co or Co-free cast superalloys [14, 15]. These alloys have almost the same strength level as their Cocontaining counterparts at elevated temperature. In fact, All of the Co-bearing and Co-free Alloy $\mathrm{K} 9$ possess the similar stress rupture life at $1050^{\circ} \mathrm{C} / 147 \mathrm{MPa}$ due to no $\mathrm{M}_{6} \mathrm{C}$ existing in cast shaped test bars, as compared between Alloy 1 and Alloy 4 in Figure 12. Thus Co-free Alloy K9 was selected to be the forging die material due to low cost consideration. Afterwards, when this alloy was utilized to cast large size die, cracks were difficult to avoid because of large quantities of $\mathrm{M}_{6} \mathrm{C}$ carbides formed in heavy section castings. Through this study, it is recognized that element $\mathrm{Co}$ is an effective retarder of primary $\mathrm{M}_{6} \mathrm{C}$; therefore, $10 \mathrm{wt} \%$ Co content for cast die alloy is necessary to prevent embrittlement caused by $\mathrm{M}_{6} \mathrm{C}$.

In Alloy K9 with $0.15 \mathrm{wt} \% \mathrm{C}$, even though $10 \mathrm{wt} \%$ Co has been added, about 0.32 vol. $\%$ primary $\mathrm{M}_{6} \mathrm{C}$ still formed in $20 \times 20 \mathrm{~mm}$ square cast bars. Therefore it is indispensable to further decrease the content of carbon. As followed Alloy 601, carbon content was controlled as to be $0.10 \mathrm{wt} \%$. The complement result showed that despite the carbon content decreases to $0.05 \mathrm{wt} \%$, Alloy 601 still maintained a $46 \mathrm{~h}$ rupture life at $1100^{\circ} \mathrm{C} / 118 \mathrm{MPa}$. In fact, many low carbon alloys such as CM247LC and CM186LC exhibited superior mechanical properties and were widely applied to gas turbine blades [16, 17]. Hence for large section castings, carbon content of alloys should be in the range of $0.04 \sim 0.07 \mathrm{wt} \%$.

\section{Conclusions}

1. Cast nickel base superalloys high in W content are suitable for casting high temperature dies. When compositions and cast processing are not controlled reasonably, three abnormal phases: primary $\mathrm{M}_{6} \mathrm{C}$ carbides, $\alpha(\mathrm{W}, \mathrm{Mo})$ and $\mu$ phase will form. Especially $\mathrm{M}_{6} \mathrm{C}$ deteriorates the high temperature strength of the alloys remarkably.

2. The primary $\mathrm{M}_{6} \mathrm{C}$ carbides begins to form from liquid at $1375^{\circ} \mathrm{C}$ and lasts to precipitate until the eutectic $\gamma^{\prime}$. Rapid cooling through solid-liquid temperature range can restrict $\mathrm{M}_{6} \mathrm{C}$ formation. As interdendritic spacing in castings is less than $50 \mu \mathrm{m}$, no $\mathrm{M}_{6} \mathrm{C}$ forms. However large blocky $\mathrm{M}_{6} \mathrm{C}$ appears in a heavy sections possessing interdendritic spacing higher than $150 \mu \mathrm{m}$.

3. It is very easy to precipitate primary carbides in alloys containing more than $18 \mathrm{wt} \%(\mathrm{~W}+\mathrm{Mo})$ and $0.15 \mathrm{wt} \% \mathrm{C}$. $10 \mathrm{wt} \%$ Co or $3 \mathrm{wt} \%$ Ru can effectively retard the formation of $\mathrm{M}_{6} \mathrm{C}$. Although carbon content below $0.05 \mathrm{wt} \%$ decreases $\mathrm{M}_{6} \mathrm{C}$ precipitation sensitivity significantly, promotes the formation of primary $\alpha(\mathrm{W}, \mathrm{Mo})$ and $\mu$ phase. Therefore it is preferred to maintain $0.04 \sim 0.07 \mathrm{wt} \% \mathrm{C}$ and $10 \sim 15 \mathrm{wt} \% \mathrm{Co}$ in alloys.

\section{Acknowledgment}

This project (contract No. 50371004) was supported by the National Natural Science Foundation of China.

\section{References}

1. W. J. Waters and J. C. Freche, "Nickel-base Alloy with Important Strength at 2000 to 2200 F," Met. Eng. Quart., 10 (2) (1970), 55-60.

2. W. J. Waters and J. C. Freche, "NASA Vane Alloy Boasts High Temperature Strength," Met. Prog., 1975, No.3: 57-61

3. S. W. K. Shaw and P. J. Penrice, "Nickel-ChromiumTantalum Alloys," U. S. Patent No.3617262, 2 November 1971.

4. S. Tin, T.M. Pollock and W.T. King, "Carbon Additions and Grain Defect Formation in High Refractory Nickel-Base Single Crystal Superalloys," Superalloys 2000, ed. T.M. Pollock et al. (Warrendale, PA: TMS, 2000), 201-210.

5. H. Harada, H. Murakami, "Design of Ni-Base Superalloys," Computational Material Design, Springer, ed. T. Saito (Berlin: Springer, 1999), 39-67

6. Y. Zheng and Y. Han, "Cost Considerations of Single Crystal Superalloys for Gas Turbine," Acta Metallurgica Sinica, 38 (12), (2002), 1203-1209.

7. Editorial Committee of China Aeronautical Materials Handbook, China Aeronautical Materials Handbook, vol. 2, (Beijing: Standards Press of China, 2002), 792-795.

8. Y. Zheng, "Development and Application of Low $\mathrm{Cr}$ and High W Content Cast Nickel Base Superalloys in China," Journal of Aeronautical Materials, Special Issue for Celebrating Aviation's 100, (2003), 227-232.

9. R. F. Allen et al., "Test Method for Determining Volume Fraction by Systematic Manual Point Count," Annual Book of ASTM Standards 2000, vol. 03.01, Designation E562-99 (West Conshohocken, PA: ASTM, 2000), 535.

10. C. T. Sims and W. C. Hagel, The Superalloys (New York; John wiley \& Sons, 1972), 479.

11. W. Kurz and B. Lux, "On the Growth of the Ni-W Eutectic," Met. Trans., 2 (1971), 329-330.

12. L. Zheng et al., "Microstructure and its Stability of a Cast Nickel Base Superalloy containing Low Level of $\mathrm{Cr}$ and High Level of W," Journal of Aeronautical Materials, 24 (1) (2004), 17-21.

13. C. H. Lund, J. Hocking and M. J. Woulds, "Casting Process for Nickel Base Alloys," U. S. Patent No. 3677331, 18 July 1972.

14. M. V. Nathal, R. D. Maier and L. J. Ebert, "The Influence of Cobalt on Microstructure of the Nickel-Base Superalloys Mar-M247," Metall. Trans (A), 13A (1982), 1775-1783.

15. Y. Koizumi, M. Yamazaki and H. Harada, "Development of 
Cobalt-free Nickel-base Superalloys," Transactions of National Research Institute for Metals, 22 (3) (1980), 32-38.

16. K. Harris et al., "Development of the Rhenium Containing Superalloys CMSX-4 \& CM186LC for Single Crystal Blade and Directional Solidified Vane Applications in Advanced Turbine Engines," Superalloys 1992, ed. S. D. Antolovich et al. (Warrendale, PA: TMS, 1992), 297-306.

17. M. Maldini et al., "Creep and Fatigue Properties of a Directionally Solidified Nickel Base Superalloy at Elevated Temperature," Superalloy 1996, ed. R. D. Kissinger et al. (Warrendale, PA: TMS, 1996), 327-334. 
